\title{
Landslide tsunami impact assessment toward human lives using numerical modelling: A case study from Banten, Indonesia
}

\author{
Muhammad Ali ${ }^{1 *}$, Teuku Rasyif ${ }^{1,2}$, and Teuku Mahli1 ${ }^{1}$ \\ ${ }^{1}$ Department of Civil Engineering, Faculty of Infrastructure Planning, Universitas Pertamina, Jl. Teuku Nyak Arief, Jakarta Selatan, \\ DKI Jakarta, 12220, Indonesia \\ ${ }^{2}$ Tsunami and Disaster Mitigation Research Center (TDMRC), Universitas Syiah Kuala, Jl. Prof. Dr. Ibrahim Hasan, Gampong Pie, \\ Banda Aceh, 23233 Indonesia
}

\begin{abstract}
After the eruption of Mount Anak Krakatoa, December 22, 2018, which was accompanied by a large landslide into the waters of the Sunda Strait, resulting a tsunami that hit South Coast of Lampung and West of Banten. According [1], 437 peoples were death, 31,942 peoples were injured and 10 peoples were lost due to this disaster. The tsunami impact toward human lives was calculated by using the human instability equation [3] and TUNAMI Two Layer model was applied to simulate the landslide and propagation of tsunami [2]. The simulation results were validated with observations and field measurements data [1]. The result of simulation showed that flow depth of the tsunami reached 0.29-5.83 $\mathrm{m}$ with the tsunami velocity about $0.23-7.49 \mathrm{~m} / \mathrm{s}$ along the shore of Pandeglang Regency. Using Aida Equation for validate simulation results, has $\mathrm{K}=0.96733$. The results of calculations using the human instability equation show that the value of hazard risk (HR) $>1$ because all critical velocity values lower than velocity of simulation. So, it was mean that tsunami waves occurred in Banten especially Pandeglang Regency has high risk impact for the balance of the human body and this condition related with the observation condition that show many victims included people died and injured in this area.
\end{abstract}

\section{Introduction}

According to geographic condition, Indonesia located among of three main tectonic plate as known as IndoAustralian, Eurasian, and Pacific. This was made Indonesia often experiences natural disaster such as earthquake and eruption of volcanic. The biggest earthquakes in Indonesia ever happened at December 26, 2004 and also made highest tsunami depth in along of Aceh. In Addition, volcanic activity in Indonesia can be categorized as very high, which is indicated by the number of active volcanoes. There are around 127 active volcanoes that make Indonesia become country with the highest number of volcanoes in the world [4]. History records major volcanic natural disasters have hit Indonesia, one of which was devastating eruption of Mount Anak Krakatau on August 27, 1883. This eruption was referred to largest, deadliest, and destructive volcanic eruption in history that caused large tsunami waves hit almost all the South Coast of Sumatra and West Coast of Java with wave height up to $30 \mathrm{~m}$ [5].

On December 22, 2018, Mount Anak Krakatau erupted again which caused landslide of caldera and triggering a tsunami wave in the Sunda Strait. The tsunami wave hit the South Coast of Lampung and West Coast of Banten with the worst affected area is Pandeglang Regency. The number of victims died was
437 people, 31,942 people was injured, and 10 people still missing [1]. The highest tsunami wave height reached $13 \mathrm{~m}$ occurred on the West Coast of Banten. Furthermore, Sunda Strait also has potential for tsunami caused by megathrust subduction tectonic [6].

Tsunami waves are classified into tectonic and volcanic tsunamis based on causative factor. Almost $90 \%$ of tsunamis in Indonesia occurs due to earthquakes at the seabed [7]. And then, factors that caused volcanic tsunamis are (1) volcanic eruptions cause by earthquakes at sea, (2) underwater volcanic eruptions, (3) pyroclastic flow (ignimbrites and nuees ardentes), (4) caldera collapse, (5) soil and cold lava rock slides, (6) base surge due to shock waves, (7) hot rock avalanches, (8) entry of lava into waters, (9) air waves due to explosions, (10) lava avalanches into the waters [8].

Pandeglang Regency is the name of a district located in Banten Province with coordinated 6. 21-7.10 LS and 104. 48 - 106 11 BT. Pandeglang Regency has administrative boundaries, namely Serang Regency for the North, Indian Ocean for the South, Sunda Strait for the West, and Lebak Regency for the East. This location has total area is around $2,746.81 \mathrm{~km}^{2}$ with 35 subdistricts and also has total population in 2019 reached $1,211,909$ people with population density of 441 people $/ \mathrm{km}^{2}$. Topography of Pandeglang Regency form

\footnotetext{
* Corresponding author: mghofurma@gmail.com
} 
with low elevation for Central and South Regions and high elevation for the North Region [9].

The location of research was conducted in the Pandeglang Regency such as Carita District and Labuan District. Carita District is focused on area of Sambolo Bay, Carita and Sukajadi Village. For Labuan District is focused on Labuan, Teluk, and Cigondang Village. This location chosen because has $\mathrm{U}$ shoreline type and fairly steep depth contour type which has high risk potential to produce highest tsunami wave. In addition, the chosen location are dominated by tourism and resident areas.

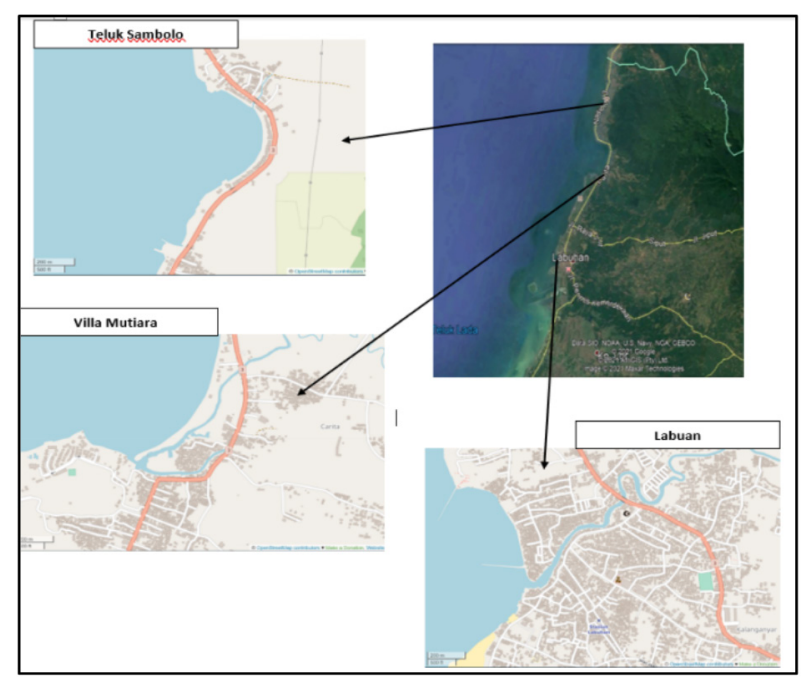

Fig. 1. Location of research

One of the risks of tsunami is inundation that rise to the ground and propagated on the mainland with certain distance. Factor that affected the distance of inundation are sand dunes, cliffs, vegetation in the coastal area, the nature and configuration of the beach, and the most influential are elevation of the beach and speed of wave propagation. The inundation of tsunami wave that hit the mainland can damage infrastructure and also pose a threat to humans due to generate hydrodynamic forces

The impact of tsunami waves that spread to mainland or inundation on human stability need to studied seriously. This study is aimed for investigating impact of the 2018 Sunda Strait tsunami on human lives at Pandeglang coastal area. Process simulation in this study applied numerical modelling to simulate the process of propagation of tsunami waves caused by landslide of Mount Anak Krakatau. To carry out the simulation process, a numerical modelling program namely TUNAMI Two-Layer [2] was used. And then, risk of inundation to humans can be assessed by modelling human instability equations. The output of simulation with TUNAMI Two-Layer and human instability modelling, author can make map classification level threat of danger to humans from hazard ratio value (HR) and expected to be reference parameter in making appropriate mitigation especially in area direct with coastal and tourist resort in Pandeglang.

The hazard ration value has been used in spatial form will indicate areas that have high risk when inundated by inundation, the value will be benchmark for how many people will be affected by brunt of tsunami inundation. The result from this study will be validate with the real condition in the impact area.

Assessment of tsunami impact caused by landslide of caldera of Mount Anak Krakatoa needs to be studied to investigate, educate and provide information about the magnitude of the impact, starting from height and velocity of tsunami wave when they hit the mainland and range of inundation. These are important factors to know hazardous area with different level of risk. Although, there is a very little probability of tsunami with same scenario in the future, as long as Mount Anak Krakatoa is still active, threat of tsunami in Banten especially in Pandeglang Regency is still exist and coupled with risk of megathrust earthquakes which pose a major threat in the future.

Research on assessment of tsunami caused landslide of caldera of Mount Anak Krakatoa to determined impact on humans using mathematical modelling that is human instability equations. However, this research still has limitation by unavailability of statistical data on distribution of affected victims in part of region especially in Carita and Labuan District. Therefore,

\section{Data and methods}

Data collection method in this research are literature study related to tsunami modelling due to landslide and using secondary data such as bathymetry and topographic data, landslide parameters, weight and height of human. Bathymetric and topographic data used to determine depth and condition of the location so best geometric shape and resolution can be reviewed by data input of simulation. Bathymetric and Topographic data obtained through National Bathymetry (BATNAS) and National Digital Elevation Model (DEMNAS) on https://tanahair.indonesia.go.id/demnas/\#/batnas.

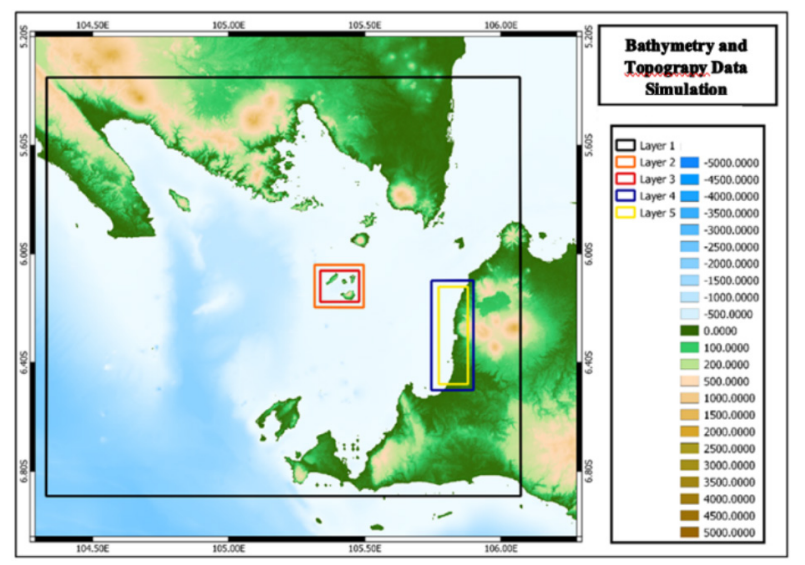

Fig. 2. Layers data of bathymetry and topography.

Grid resolution of both data are $185 \mathrm{~m}$ and $8 \mathrm{~m}$. In this research, grid layer will be divided into five layers with grid resolution are $180 \mathrm{~m}, 60 \mathrm{~m}, 20 \mathrm{~m}, 60 \mathrm{~m}$, and $20 \mathrm{~m}$. First layer until third layer are using for simulating area of landslide Anak Krakatau Mountain and propagation of tsunami in sea. Fourth and fifth layer are using for simulating propagation tsunami in mainland. Processing to get layer data from bathymetry and topography using Generic Mapping Tools (GMT), Quantum GIS (QGIS), and Fortran software. 
Table 1. Setting Input Data Layer

\begin{tabular}{|c|c|c|c|}
\hline \multirow{2}{*}{ Location } & \multirow{2}{*}{ Grid Size (m) } & \multicolumn{2}{|c|}{ Coordinate } \\
\cline { 3 - 4 } & & Minimum & Maximum \\
\hline Layer 1 & 180 & $(104.320 ;-6.903)$ & $(106.078 ;-5.345)$ \\
\hline Layer 2 & 60 & $(105.314 ;-6.201)$ & $(105.495 ;-6.040)$ \\
\hline Layer 3 & 20 & $(105.300 ;-6.180)$ & $(105.478 ;-6.066)$ \\
\hline Layer 4 & 60 & $(105.779 ;-6.500)$ & $(105.903 ; 6.250)$ \\
\hline Layer 5 & 20 & $(105.750 ;-6.500)$ & $(105.961 ;-6.250)$ \\
\hline
\end{tabular}

Landslide mechanism data is used to determine movement of landslide and triggering tsunami waves. Landslide mechanism data in this research still adheres by [2] because process of landslide modelling has a fairly complicated with sophisticated computer specification. Landslide parameter data obtained from research data by [2] are maximum height of landslide and sliding time. Maximum height of landslide and sliding time is around $301,2 \mathrm{~m}$ and 10.8 minutes with landslide volume reaching $0.182 \mathrm{~km}^{2}$. These data are one of important parameters for input in TUNAMI TwoLayers. This modelling will simulate landslide that triggered tsunami by modelling interaction between tsunami waves and subaerial-submarine landslide as top and bottom layers [2]. TUNAMI Two-Layer using governing equations as follows:

a. First layer equation

Using continuity equation as follows:

$$
\frac{\partial \mathrm{Z}_{1}}{\partial \mathrm{t}}+\frac{\partial \mathrm{Q}_{1 \mathrm{x}}}{\partial \mathrm{x}}+\frac{\partial \mathrm{Q}_{1 \mathrm{y}}}{\partial_{\mathrm{y}}}=0
$$

Using momentum equation at $\mathrm{x}$ and $\mathrm{y}$ directional that write as follows:

$$
\begin{aligned}
& \frac{\partial Q_{1 x}}{\partial t}+\frac{\partial}{\partial x}\left(\frac{Q^{2}{ }_{1 x}}{D_{1}}\right) \\
& +\frac{\partial}{\partial y}\left(\frac{Q_{1 x} Q_{1 y}}{D_{1}}\right)+g D_{1} \frac{\partial Z_{1}}{\partial x} \\
& +g D_{1} \frac{\partial Z_{2}}{\partial x}+\tau_{1 \mathrm{x}}=0 \\
& \frac{\partial Q_{1 y}}{\partial t}+\frac{\partial}{\partial x}\left(\frac{Q_{1 x} Q_{1 y}}{D_{1}}\right) \\
& +\frac{\partial}{\partial y}\left(\frac{Q^{2}{ }_{1 y}}{D_{1}}\right)+g_{1} \frac{\partial Z_{1}}{\partial y} \\
& +g D_{1} \frac{\partial Z_{2}}{\partial y}+\tau_{1 y}=0
\end{aligned}
$$

b. Second layer equation

Using continuity equation as follows:

$$
\frac{\partial \mathrm{Z}_{2}}{\partial \mathrm{t}}+\frac{\partial \mathrm{Q}_{2 \mathrm{x}}}{\partial \mathrm{x}}+\frac{\partial \mathrm{Q}_{2 \mathrm{y}}}{\partial_{\mathrm{y}}}=0
$$

Using momentum equation at $\mathrm{x}$ and $\mathrm{y}$ directional that write as follows:

$$
\begin{aligned}
& \frac{\partial \mathrm{Q}_{2 \mathrm{x}}}{\partial \mathrm{t}}+\frac{\partial}{\partial \mathrm{x}}\left(\frac{\mathrm{Q}^{2}{ }_{2 \mathrm{x}}}{\mathrm{D}_{2}}\right) \\
& +\frac{\partial}{\partial \mathrm{y}}\left(\frac{\mathrm{Q}_{2 \mathrm{x}} \mathrm{Q}_{2 \mathrm{y}}}{\mathrm{D}_{2}}\right)+\mathrm{gD}_{2} \frac{\partial \mathrm{Z}_{2}}{\partial \mathrm{x}} \\
& +\mathrm{gD}_{2} \frac{\rho_{1}}{\rho_{2}} \frac{\partial \mathrm{Z}_{1}}{\partial \mathrm{x}}+\tau_{2 \mathrm{x}}=0 \\
& \frac{\partial \mathrm{Q}_{2 \mathrm{y}}}{\partial \mathrm{t}}+\frac{\partial}{\partial \mathrm{x}}\left(\frac{\mathrm{Q}_{2 \mathrm{x}} \mathrm{Q}_{2 \mathrm{y}}}{\mathrm{D}_{2}}\right) \\
& +\frac{\partial}{\partial \mathrm{y}}\left(\frac{\mathrm{Q}^{2}}{\mathrm{D}_{2}}\right)+\mathrm{gD}_{2} \frac{\partial \mathrm{Z}_{2}}{\partial \mathrm{y}} \\
& +\mathrm{gD} \frac{\rho_{1}}{\rho_{2}} \frac{\partial \mathrm{Z}_{1}}{\partial \mathrm{y}}+\tau_{1 \mathrm{y}}=0 \\
& \rho_{2}=(1-\vartheta) \rho_{g}+\vartheta \rho_{1}
\end{aligned}
$$

Where $\rho_{1}, \rho_{g}, \rho_{2}$, and $\vartheta$ is density of seawater, granular material, sediment, and porosity. In this modelling, fluidized precipitate is hypothesized as immiscible. Index 1 and 2 relates to the upper layer and second layer. $\mathrm{Z}(\mathrm{x}, \mathrm{y}, \mathrm{t}), \mathrm{i}=1,2$ is the level of layer at each point $(\mathrm{x}, \mathrm{y})$ at time $\mathrm{t}$, where the level value is measured from a given reference level. $\mathrm{Q}(\mathrm{x}, \mathrm{y}, \mathrm{t}), \mathrm{i}=1,2$ is the vertically integrated discharge in the $\mathrm{x}$ and $\mathrm{y}$ directions. $\tau_{\mathrm{i}}(x, y, t)$ is the bottom stress in each layer at each points $(x, y)$ at time $\mathrm{t}$. In this study, parameters were kept fixed as follows: water density $=1,000 \mathrm{~kg} / \mathrm{m}^{3}$, landslide density $=2,000 \mathrm{~kg} / \mathrm{m}^{3}$, and manning coefficient $=0,025$ [2].

The simulation results will validate using observational data by [3]. Validation analysis using Aida equation, sum square error (SE), mean square error (MSE), root mean square error (RMSE). Observational data that using in this study located on Marina Jambu tidal gauge with 49 points locations. Validation using Aida equation will result two parameter values of $\mathrm{K}$ and $\mathrm{k}$, which is compared with standard of Japan Society of Civil Engineering (JSCE). Based on JSCE, best recommended value of $\mathrm{K}$ and $\mathrm{k}$ is $0.95<\mathrm{K}<1.05$ and $\mathrm{k}$ $<1.45$. Aida equations write as follows.

$$
\begin{aligned}
& \log K=\frac{1}{n} \sum_{i=1}^{n} \log K_{i} \\
& \log k=\sqrt{\frac{1}{n} \sum_{i=1}^{n}\left(\log K_{i}\right)^{2}-(\log }
\end{aligned}
$$

$$
K_{i}=\frac{x_{i}}{y_{i}}
$$


Where variable of $x_{i}$ is observational data and $y_{i}$ is simulation data. Human instability modelling needed data of human weight and height were used for input data. These data based on research by [3]. Analysis of human instability using five equations that developed by $[11][12][3][13][14]$ with result of this equations is critical velocity. Five human instability equations write as follows:

1) Abt, et al. (1989)

$$
D U_{C}=0.0929\left(e^{0.001906 H M+1.09}\right)^{2}
$$

2) Karnoven, et al. (2000)

$$
D U_{C}=0.004 H M+0.2
$$

3) Ramsbottom, et al. (2004)

$$
D\left(U_{C}+0.5\right)+D=\text { Hazard Levヶ }
$$

4) Lind and Hartford (2000)

$$
D U_{C}=K_{0} M^{0.5}
$$

5) Jonkman and Penning-Roswell (2008)

a. Momentum

$$
D U_{C}=\left(\frac{2 H M g \cos \alpha}{C_{D} \beta \rho}\right)^{0.5}
$$

b. Friction

$$
D U_{C}^{2}=\frac{2 \mu g M}{C_{D} \beta \rho}
$$

This value will be used to calculate HR value at each location. Therefore, it is possible to know level of hazard risk at each location and make easily to facilitate the proper mitigation planning process. Analysis process of human instability in this study using Fortran to get critical velocity value and QGIS for illustrated HR values in spatial model. Equation to get $\mathrm{HR}$ value as follows:

$$
H R=\frac{U_{S}}{U_{C}}, \quad H R \leq 1
$$

\section{Results and discussion}

\section{a. Validation}

Validation using Aida Equation produces two parameter values namely $\mathrm{K}$ and $\mathrm{k}$ are 0.967 and 1.691 . Based on JSEC standards, value of $\mathrm{k}$ does not meet requirements and it is mean that accuracy of simulation data is not good. The value of $\mathrm{k}$ does not meet JSCE standard because boundary equation used in TUNAMI TwoLayer not include parameter of building effect, even though it has effect in flow of tsunami wave in the field.
According [10], building barriers can increase tsunami wave flow resistance relatively in modelling compared absence of barriers. Therefore, including building parameter in modelling become problem limitation, so that results of wave height tsunami become less accurate.

Then, validation using root mean square errorobservations standard deviation ratio (RMSE-SR) and Nash-Sutcliffe effiecency (NSE) produce values of 0.453 and 0.547 . If RMSE-SR and NSE value is $0<\mathrm{RMSE} \_\mathrm{SR} \leq 0.5$ and $0.36<\mathrm{NSE} \leq 0.75$, which means that the simulation results have a very good level of accuracy and interpretation of result data is qualified. Moreover, result of simulation also calculate using coefficient of relation (R), the following values are 0.462 . This value in the category of sufficient accuracy because in range of $0.25 \leq R \leq 0.5$. So, based on calculation of Aida equations, RMSE-SR, NSE, and category of sufficient, it can be concluded that the simulation data have interpretation as qualified data and good be used as data reference for further analysis.

\section{b. Initial condition}

Simulation result can display as spatial of Mount Anak Krakatau when it has landslide for 10 minutes. In addition, sea water level changes shown when landslide occurs.

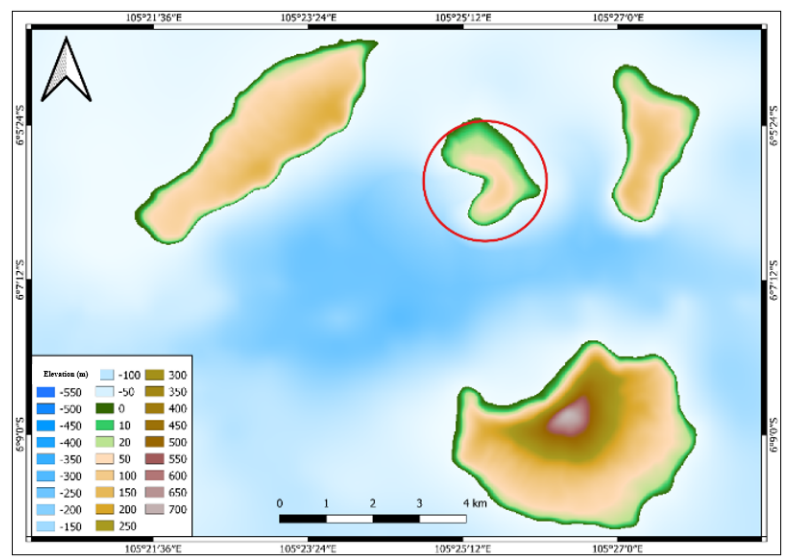

Fig 3. Area of landslide

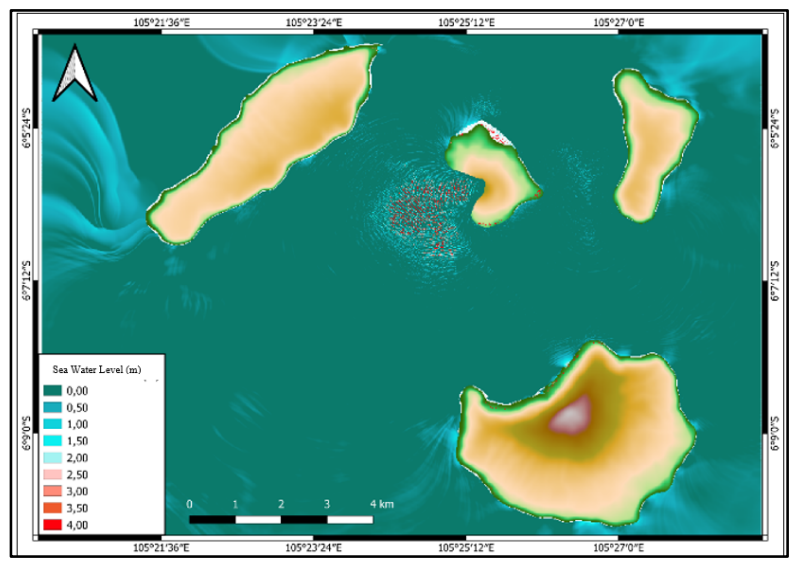

Fig 4. Change of sea water level 


\section{c. Wave height of tsunami}

Wave height at Carita and Sukajadi Villages are dominated by 4-5 $\mathrm{m}$ with inundation range of 200-800 $\mathrm{m}$. The magnitude of dominating wave height is $72.894 \%$ of total simulation data.

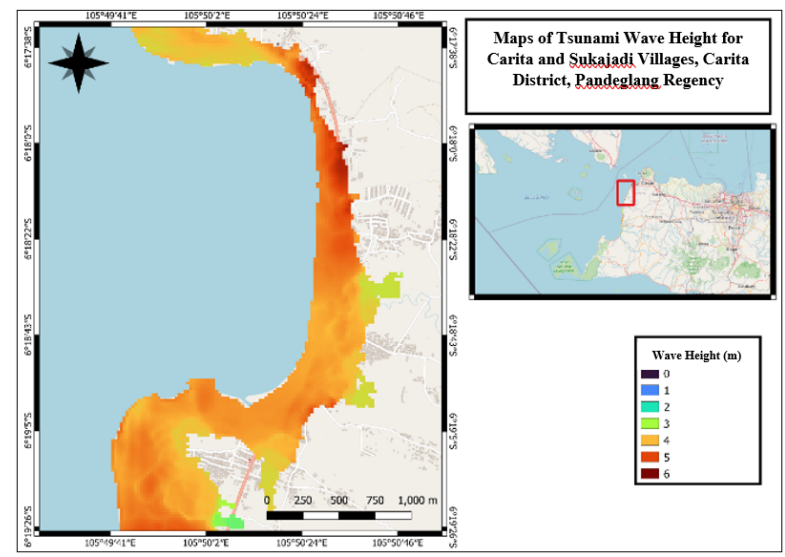

Fig 5. Wave height in Carita and Sukajadi

Wave height at Sambolo Bay is dominated by 3-4 m with inundation range of 400-500 m. The magnitude of dominating wave height is $80.030 \%$ of total simulation data.

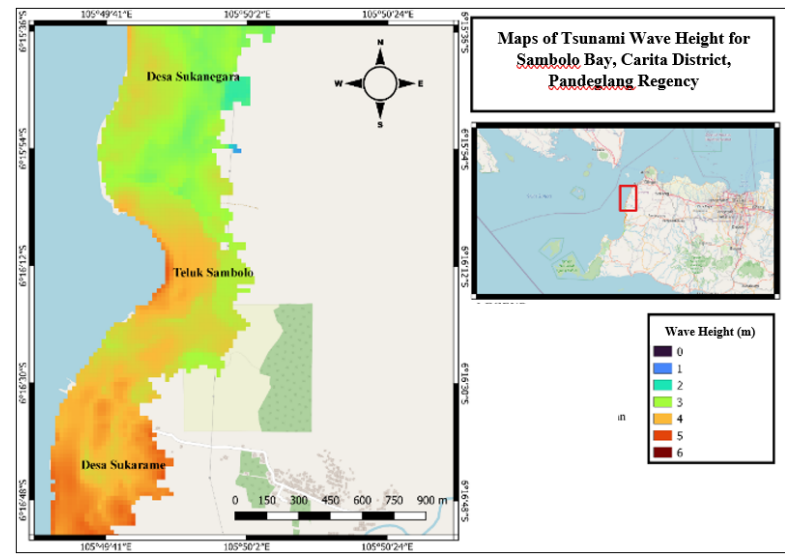

Fig 6. Wave height in Sambolo Bay

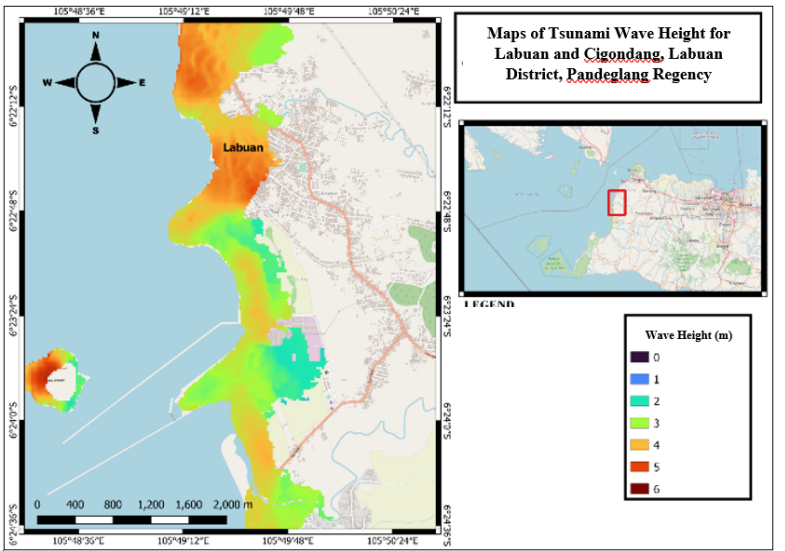

Fig 7. Wave height in Labuan and Cigondang Villages

Wave height at Labuan and Cigondang Villages are dominated by 3-4 $\mathrm{m}$ with inundation range of 500-1500 $\mathrm{m}$. The magnitude of dominating wave height is $47.5 \%$ of total simulation data.
Based on simulation results of tsunami wave height at three locations, it can be concluded that tsunami waves are dominated by height above $2 \mathrm{~m}$ with highest tsunami waves in the coastline area reaching 4-6 m. Tsunami wave that hit the coastline are became highest due to factors from changes in wavelength of tsunami from deep waters to shallow waters, sea depth, and shape of coastline. When tsunami waves reach land and inundated, their height will decrease according to elevation height and level of soil roughness at the scene. Tsunami wave height that exceeds $3 \mathrm{~m}$ is classified as a tsunami wave which is very dangerous for both building structures and humans. This is one of the assessment parameters that be used as hazard risk analysis and mitigation planning in tsunami-affected areas [15].

\section{d. Wave velocity of tsunami}

Velocity of tsunami waves in Sambolo Bay dominated by $3-4 \mathrm{~m} / \mathrm{s}$ with percentage of $3-4 \mathrm{~m} / \mathrm{s}$ and on shoreline has $4 \mathrm{~m} / \mathrm{s}$, it means that velocity is very fast and dangerous. Furthermore, tsunami waves in Sambolo also have a very high wave.

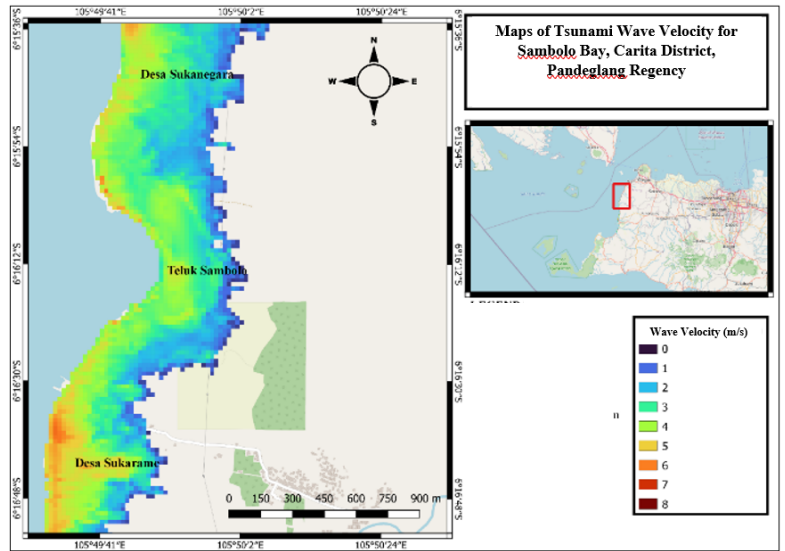

Fig 8. Tsunami wave velocity in Sambolo Bay

Velocity of tsunami waves in Carita and Sukajadi dominated by $2-3 \mathrm{~m} / \mathrm{s}$ with percentage data of $23.737 \%$ and on the shoreline is $4-7 \mathrm{~m} / \mathrm{s}$.

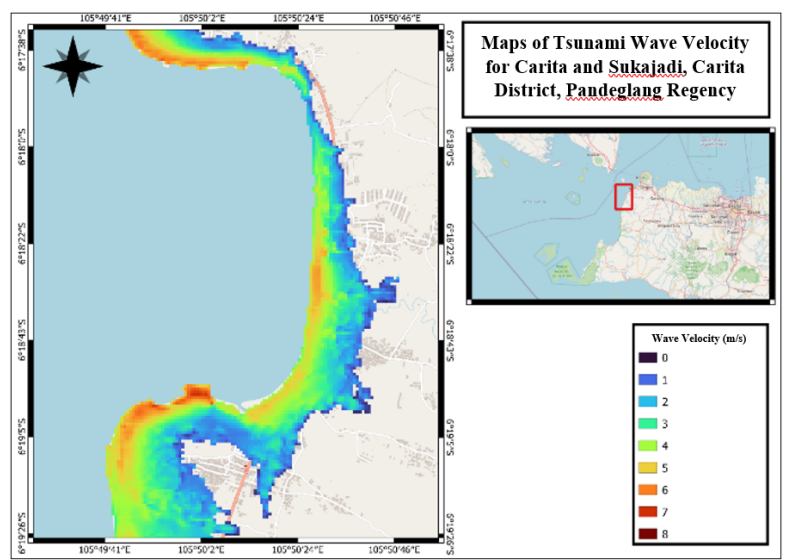

Fig 9. Tsunami wave velocity in Carita and Sukajadi Villages

Then, velocity of tsunami wave in Labuan and Cigondang dominated by $3-4 \mathrm{~m} / \mathrm{s}$ with percentage 
$27.601 \%$ and on the shoreline of area is $4-6 \mathrm{~m} / \mathrm{s}$. This value same to case of Sambolo Bay.

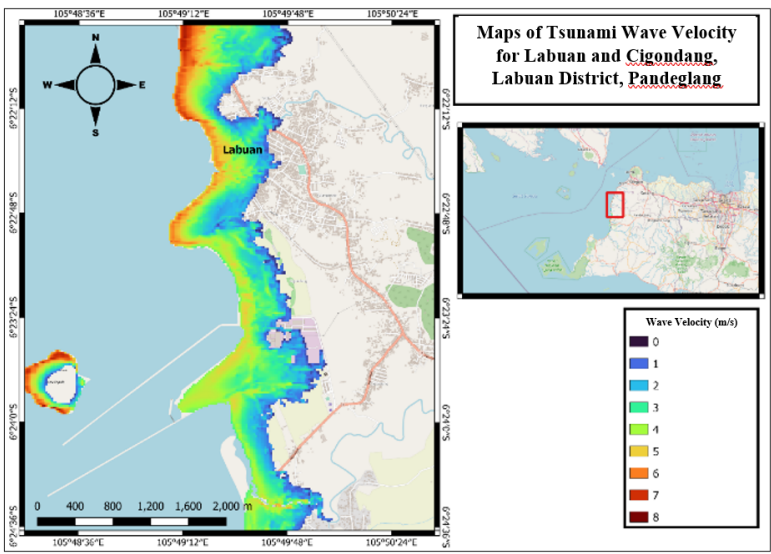

Fig 10. Velocity of tsunami wave in Labuan and Cigondang villages

Based on the simulation result, velocity of tsunami wave in three locations are dominated by more than $2 \mathrm{~m} / \mathrm{s}$. this velocity is relatively fast and increases risk of danger because it is accompanied by a fairly high tsunami height. Velocity of wave tsunami in this location became fast because factor of depth of sea and elevation along the shoreline.

\section{e. Time arrival of tsunami}

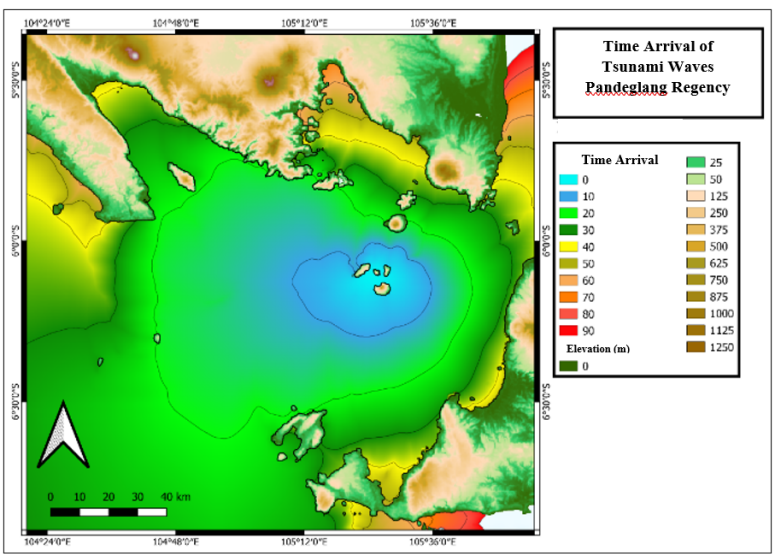

Fig 11. Time arrival of tsunami wave in Pandeglang Regency.

First tsunami wave reached shoreline in Sambolo Bay, Carita-Sukajadi Village, and Labuan-Cigondang Village in time of 36 minutes, 37 minutes, and 43 minutes. It is important to analyze time of tsunami wave propagation to determine mitigation process such as determined evacuation route and locations.

\section{f. Human instability and hazard ratio analysis}

The results of the calculation from data sample using five human instability equations show that Karnoven equation resulted best estimated compared to other equations. So, in this study, result from calculation using Karnoven equation would be used to calculate hazard ratio. The Output from calculation of human instability is critical velocity. For Sambolo Bay case has critical velocity for male dominated by $0.050-0.059 \mathrm{~m} / \mathrm{s}$ with percentage of $44.444-57.658 \%$ and $0.060-0.069 \mathrm{~m} / \mathrm{s}$ with percentage of $42.417-52.327 \%$. This value for case of age 4-12 years and above 12 years. Then, female case has same value from male case, just different in percentage value. So, Sambolo Bay has HR value for any range of age is $H R=1$.

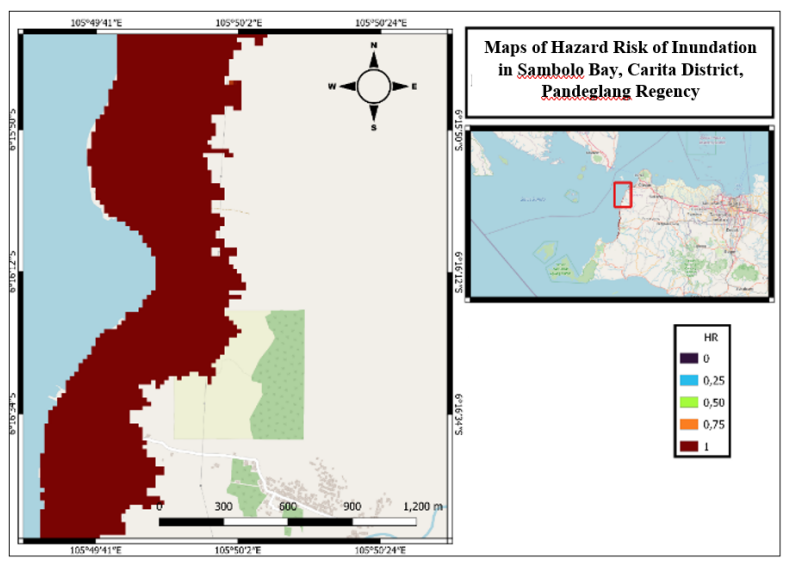

Fig 12. Hazard ratio spatial distribution for Sambolo Bay

For Carita and Sukajadi case, dominated critical velocity for male case are $0.040-0.049 \mathrm{~m} / \mathrm{s}$ with percentage of $48.181-60.165 \%$ and $0.050-0.059 \mathrm{~m} / \mathrm{s}$ with percentage of 59.361-70.444\%. This value for case of age 4-9 years and above 9 years old. For female case, value of critical velocity has same with male case, just different in percentage point. In this location also has $\mathrm{HR}=1$, because velocity of tsunami height larger than critical velocity itself.

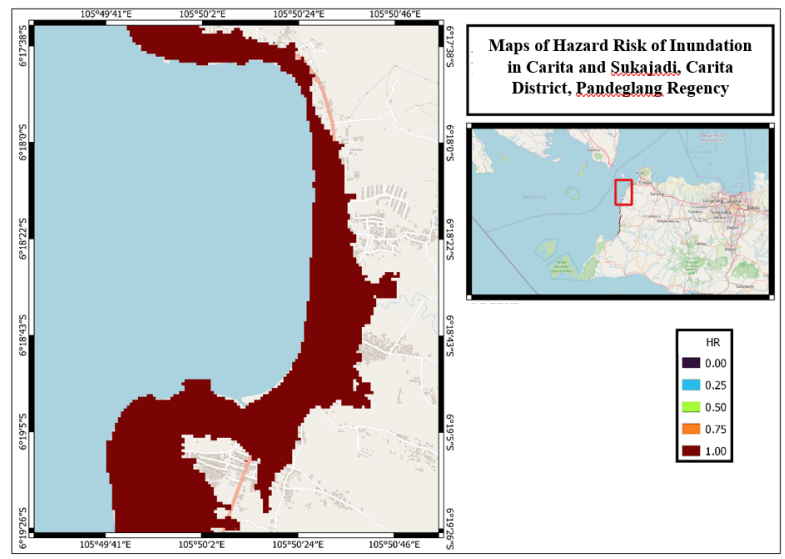

Fig 13. Hazard ratio spatial distribution for Carita and Sukajadi villages

For Labuan and Cigondang case, value of critical velocity for male case dominated by $0.050-0.069 \mathrm{~m} / \mathrm{s}$ with percentage of $45.900 \%-54.068 \%$. This value for case of age 4 year until above 80 years old. For female case, value of critical velocity has same with male case just different in percentage distribution. HR value in this location also has $\mathrm{HR}=1$, same like with other location. 


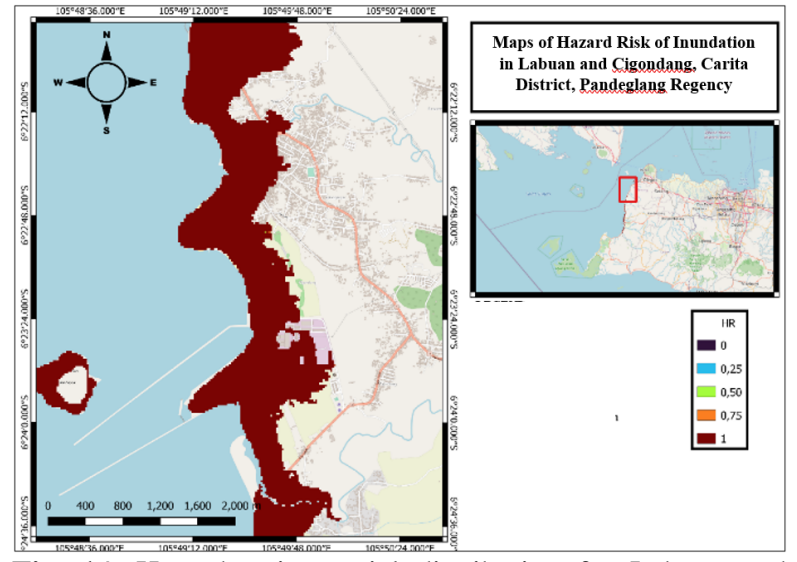

Fig. 14. Hazard ratio spatial distribution for Labuan and Cigondang villages

The result of HR calculations shows $H R=1$ for all location in this study, it shows that humans who are in the red zone will not be able to maintain their body balance when exposed to tsunami waves. As the result, humans will be carried away by current of tsunami and caused several possibilities that occurs as surviving without being injured, injured and dead. Based on interim report [16] at December 22, 2018, number of victims in Carita District are 50 people died and 50 people injured. Meanwhile in Labuan District there are 6 people died and 50 people injured. This data show that tsunami occurred in both locations poses a risk to human lives, although data is not detailed and is not final result. However, overall report of final victim data released by [1], the number of victims died was 437 people, 31,942 people was injured, and 10 people still missing. In addition, Carita and Labuan District were two most severely affected by tsunami based on [16]. This indicates that the results of analysis of human instability are in line with actual condition in the field based on risk distribution mapping in Figure 12, Figure 13, and Figure 14.

\section{Conclusions}

Result in this study showed that tsunami waves caused by landslide of Mount Anak Krakatau had a dominant height wave of above $2 \mathrm{~m}$ with velocity over $2 \mathrm{~m} / \mathrm{s}$. Meanwhile, critical velocity that can received by humans only under $1 \mathrm{~m} / \mathrm{s}$. Therefore, value of hazard risk is $\mathrm{HR}=1$, which means all area in this study that were inundated by tsunami are unsafe for stability of human body and this analysis are in line with actual condition in the field based on risk distribution mapping. Further study is needed to investigate human risk due to tsunami by applying high resolution data and detail data of victims report including death and injured at any area of study to validation simulation results and human instability equation. Furthermore, using other possibility scenario to enhance mechanism of tsunami disaster in the future and also can preparing step of disaster mitigation.
Acknowledgement. Authors are very grateful to supports received from Dr. Kwanchai Pakoksung, IRIDeS, Tohoku University for providing the TUNAMI Two-Layers model for this study.

\section{References}

1. Syamsidik, Benazir, M. Luthfi, A Suppasri, L. K. Comfort. Natural Hazards and Earth System Sciences. 20 (2020) 549-585

2. K. Pakoksung, A. Suppasri, A. Muhari, F. Imamura. Geoscience Letters 7 (2020) 1-20.

3. R. Nakamura, M. Mäll, T. Shibayama. Natural Hazard. 99 (2019) 391-422.

4. Center of Volcanology Survey of Indonesia. Citation from https://www.vsi.esdm.go.id/index.php/kegiatanpv mbg/kegiatan-diseminasi-informasi/2829-pressreleaseaktivitas-vulkanik-g-anak-krakatau-31desember-2019. (January, 2019)

5. Sutawijaja, I. The Disaster Prevention Research Institute Annuals. 40 (1997)

6. Maemo, F., \& Imamura, F. Indonesia Jurnals Geopysh Res. 116 (2011)

7. Latief, H., Puspito, \& Imamura. Tsunami Catalog and Zones in Indonesia. 22 (2000) 25-43

8. Latter, J. H. Bulletin Volcanologique. (1981) 467490

9. Statistic Center Institution (BPS). Kabupaten Pandeglang Dalam Angka 2020. (2020) 1-25

10. Aida, I. J. Phys Earth. (1978) 57-73

11. Abt, S., Wittler, Taylor, \& Love. J Am Water Resour As. 25 (1989) 881-890

12. Flooad Hazard Research Centre, Middlesex University Risk, \& Policy Analysis. FD2321/TR2 Guidance Document. (2006)

13. Lind, Hartford, \& Assaf. J Am Water Resour. (2004) 89-96

14. Jokman \& Penning-Roswell. J Am Water Resour. 44 (2008) 5-15

15. Rahmawan. Studi Potensi Bahaya Tsunami di Selatan Jawa. (2012)

16. National Board Disaster Management (BNPB). Citation from https://bpbd.bantenprov.go.id/read/berita/240/LA PORAN-SEMENTARA-TSUNAMI-BANTEN. (December, 2018). 